\title{
Evaluation of Biogenic Characteristics of Iron Nanoparticles and Its
} Alloys in Vitro

\author{
Elena Yausheva ${ }^{2}$, Elena Sizova ${ }^{1,2} \&$ Sergey Miroshnikov ${ }^{2}$ \\ ${ }^{1}$ Orenburg State University, Orenburg, Russia \\ ${ }^{2}$ State Educational Institution All-Russian Research Institute of Beef Cattle Breeding, Orenburg, Russia \\ Correspondence: Elena Yausheva, State Educational Institution All-Russian Research Institute of Beef Cattle \\ Breeding, Orenburg, Russia Tel: 8-987-850-07-15. E-mail: vasilena56@mail.ru
}

Received: August 10, 2015

Accepted: August 25, 2015

Online Published: August 30, 2015

doi:10.5539/mas.v9n10p65

URL: http://dx.doi.org/10.5539/mas.v9n10p65

\begin{abstract}
This research was performed to study the effect of iron nanoparticles with variable size, its oxides and alloys on living systems. Analysis of the results showed manifestation of acute toxicity over a wide concentration range for FeCo alloy nanoparticles and low toxic characteristics for iron nanoparticles and its oxides. To develop acute toxicity high concentrations of iron nanoparticles and iron oxide nanoparticles were required. Calculation of toxicity index allowed to rank studied nanoparticles samples in descending order of toxic action: $\mathrm{FeCo} \rightarrow \mathrm{Fe}^{\mathrm{a}} \rightarrow$ $\mathrm{Fe}_{3} \mathrm{O}_{4}{ }^{\mathrm{a}} \rightarrow \mathrm{Fe}^{\mathrm{b}}=\mathrm{Fe}_{3} \mathrm{O}_{4}{ }^{\mathrm{b}}$.

Correlation was direct between particle size and the intensity of the impacton living systems. According to obtained data,the smaller the particle size the greater its biological activity. The presence of cobalt in the alloy FeCo nanoparticles contributed to the increase of biological activityand as a consequence increase toxic effects.

These studies revealed biological activity of iron nanoparticle and its oxides without development of toxic effect at doses of $0.25-0.000718 \mathrm{M}$ which characterizes them as biotic.
\end{abstract}

Keywords: nanoparticles, iron, luminescence

\section{Introduction}

Evaluation of nanomaterials characteristics is one of the most important trends in modern biology (Jiang et al., 2015; Liu et al., 2015). Search for nanoforms with no toxic effect both in small and large quantities is necessary considering accumulation of nanomaterials in the environment and development of preparations based on them (Ajdary et al., 2015; Gong et al., 2015; Dragavon et al., 2012; Melancon et al., 2012).

Effective and general method to study the biological activity of nanoparticles in relation to living systems is to assess value of microorganism's bioluminescence under their influence.

Preparations based on metal nanoparticles and their derivatives are widespread in biology. Therefore this study shall include assessment of biological activity not only of metal nanoparticles but also of their oxides and alloys with other metals.

\section{Materials and Methods}

The test object was genetically engineered luminescent strain Escherichia coli K12 TG1 constitutively expressing luxCDABE genes of natural marine microorganism Photobacterium leiongnathi 54D10 which was produced by the SIS "Immunotech" (Russia, Moscow) in lyophilized condition under the commercial name "Ecolum". Immediately before the test the strain Echerichia coli K12 TG1 was restored by addition of chilled distilled water. The suspension of bacteria was maintained at $+2-4{ }^{\circ} \mathrm{C}$ for $30 \mathrm{~min}$ after which the temperature of the bacterial suspension was brought to $15-25^{\circ} \mathrm{C}$.

The inhibition of bacterial luminescence was tested by placing into the cells in 96-well plates the test substance and the suspension of luminescent bacteria in a 1:1 ratio. Subsequently, the tray was placed in the measuring unit of an Infinite PROF200 microplate analyzer (TECAN, Austria) which dynamically registered the luminescence intensity for $180 \mathrm{~min}$ at intervals of $5 \mathrm{~min}$. The effects of the nanomaterials on the intensity of bacterial bioluminescence (I) were evaluated using the formula: $=\frac{I k_{\text {омин }} \times I o_{\text {пмин }}}{I k_{n \text { мин }} \times I o_{\text {Омин }}}$, where $I k$ and $I o$ are the illumination 
intensities of the control and experimental samples, respectively, from the 0 -th and $n$-th minutes of measurement. Three threshold levels of toxicity are taken into account:

1. less than 20 - a sample of "non-toxic" (luminescence quenching $\leq 20 \%$ );

2. 20 to 50 - a sample of relatively toxic (luminescence quenching $50 \%$ );

3 is equal to or greater than 50 - the sample is toxic (luminescence quenching $\geq 50 \%$ ).

In studies commercial samples of metal nanoparticles "Advanced Powder Technology", Russia were used (Table $1)$.

The metal nanoparticle samples were characterized (particle size, polydispersity, volume, quantitative content of fractions, surface area) by electronic scanning, translucent, atomic-powered microscopy using LEX T OLS4100, JSM 7401F, JEM-2000FX ("JEOL", Japan). The size distribution of particles was investigated using a Brookhaven 90Plus /BIMAS and ZetaPALS Photocor Compact (Russia) in the sol after dispersing the nanoparticles using an ultrasonic disperser UZDN-2T (Russia) at f-35 kHz, N-300 W, and A-10 $\mu$ a for 30 min.

Samples of nanoparticles suspensions for test were prepared under $4 \mathrm{M}-6 \times 10^{-6} \mathrm{M}$ concentration and treated by ultrasonic for $30 \mathrm{~min}$.

Table 1. Nanoparticle characterization

\begin{tabular}{|c|c|c|c|c|c|}
\hline $\begin{array}{l}\text { The name of the } \\
\text { nanoparticles }\end{array}$ & $\begin{array}{l}\text { SSize, } \\
\mathrm{nm}\end{array}$ & $\begin{array}{l}\text { Chemical and phase } \\
\text { composition }\end{array}$ & $\begin{array}{l}\text { Method of } \\
\text { production }\end{array}$ & $\begin{array}{l}\text { Specific surface } \\
\text { area }\left(\mathrm{S}_{\mathrm{v}} \mathrm{m}^{2} / \mathrm{g}\right)\end{array}$ & $\begin{array}{l}\text { Z-potential, } \\
\mathrm{mV}\end{array}$ \\
\hline $\mathrm{Fe}^{\mathrm{a}}$ & 80 & $\mathrm{Fe}_{3} \mathrm{O}_{4}, \alpha-\mathrm{Fe}_{2} \mathrm{O}_{3}$ & Gas-phase & 15 & $15 \pm 0,2$ \\
\hline $\mathrm{Fe}^{\mathrm{b}}$ & 90 & $\begin{array}{r}\text { metallic iron (not less } \\
99,8 \% \text { by mass) and } \\
\text { sorbed gases }-\mathrm{CH}_{4} \\
\mathrm{CO}_{2}, \mathrm{Ar}, \mathrm{N}_{2} .\end{array}$ & $\begin{array}{r}\text { The electric } \\
\text { explosion of } \\
\text { wire in an } \\
\text { argon } \\
\text { atmosphere }\end{array}$ & 7,7 & $13 \pm 0,5$ \\
\hline $\mathrm{Fe}_{3} \mathrm{O}_{4}{ }^{\mathrm{a}}$ & 65 & $\begin{array}{r}\mathrm{Fe}_{3} \mathrm{O}_{4} \text { not less } 99 \% \text { by } \\
\text { mass. About } 1 \% \text { by } \\
\text { mass adsorbed gases - } \\
\quad\left(\mathrm{CH}_{4}, \mathrm{CO}_{2}, \mathrm{O}_{2}, \mathrm{~N}_{2}\right)\end{array}$ & $\begin{array}{r}\text { The electric } \\
\text { explosion of } \\
\text { wire in an air } \\
\text { atmosphere }\end{array}$ & 10 & $19 \pm 0,5$ \\
\hline $\mathrm{Fe}_{3} \mathrm{O}_{4}{ }^{\mathrm{b}}$ & 95 & $\mathrm{Fe}_{3} \mathrm{O}_{4} 99 \%$ by mass & Chemical & 20 & $15 \pm 0,5$ \\
\hline $\mathrm{FeCo}$ & 62,5 & $\begin{array}{r}70 \% \text { of iron and } 30 \% \\
\text { of cobalt }\end{array}$ & Gas-phase & 11 & $29 \pm 0,5$ \\
\hline
\end{tabular}

All experiments were done in triplicate and processed by variation statistics using the software package Statistika V8 (StatSoft Inc., USA).

\section{Results}

Obtained results characterize the dynamics of inhibition of bacterial bioluminescence over time and demonstrate dependence on the nature of the investigated nanomaterials along with their forms and concentrations.

The contact of $E$. coli with increasing concentrations of $\mathrm{Fe}^{\mathrm{a}}$ nanoparticles in the range of 4 to $0.25 \mathrm{M}$ lead to complete suppression of illumination in the test object and manifestation of an acute toxicity in relation to living system in the first 80-90 minutes of contact (Figure 1, a). 



Figure 1. Dynamics of luminescence of $E$. coli K12 TG1 with cloned luxCDABE genes of P. leiongnathi 54D10 in contact with different concentrations of nanoparticles of $\mathrm{a}-\mathrm{Fe}^{\mathrm{a}}$ and $\mathrm{b}-\mathrm{Fe}^{\mathrm{b}}$

0,5(1) M; 0,25 (2) M; 0,1 (3) M; 0,05 (4) M; 0,025 (5) M; 0,0125 (6) M; 0,00625 (7) M; 0,003125 (8) M; 0,00156 (9) M; 0,000781 (10) M; c - control

Subsequent dilutions of suspensions at concentrations 0,1 and $0.05 \mathrm{M}$ lead to $50 \%$ inhibition of bacterial bioluminescence of the test organism at all stages of incubation time which indicates relative or subacute toxicity of tested concentrations. The concentration of $0.025 \mathrm{M} \mathrm{Fe}^{\mathrm{a}}$ nanoparticles caused only $30 \%$ inhibition of bacterial bioluminescence after 160 min demonstrating a weak toxic effect. Concentration range of $\mathrm{Fe}^{\mathrm{a}}$ nanoparticles from 0.0125 to $6 \times 10^{-6} \mathrm{M}$ had no significant effect on dynamics of microorganism luminescence.

In contrast to the above $\mathrm{Fe}^{\mathrm{b}}$ nanoparticles caused $50 \%$ inhibition of bacterial luminescence during the whole time of contact at a dose $>0.25 \mathrm{M}$ which is 5 times more than the $\mathrm{EC}_{50} \mathrm{Fe}^{\mathrm{a}}$ (Figure 1, b).

The concentration range of $\mathrm{Fe}^{\mathrm{b}}$ nanoparticles from 0.25 to $0.1 \mathrm{M}$ demonstrated weak toxic effect causing $30 \%$ inhibition of bacterial bioluminescence. Further dilution of $\mathrm{Fe}^{\mathrm{b}}$ nanoparticles ranging from 0,05 to $6 \times 10^{-6} \mathrm{M}$ were characterized by the absence of a significant effect on bioluminescence microorganisms.

Iron oxide nanoparticles were in the intermediate position in the rank of toxicity. $\mathrm{Fe}_{3} \mathrm{O}_{4}{ }^{\mathrm{a}}$ nanoparticles showed toxic effects at lower concentrations compared to $\mathrm{Fe}_{3} \mathrm{O}_{4}{ }^{\mathrm{b}}$ nanoparticles. Thus $50 \%$ inhibition of bioluminescence in contact of $E$. Coli with $\mathrm{Fe}_{3} \mathrm{O}_{4}{ }^{\mathrm{b}}$ nanoparticles occurred at a concentration of $>0.25 \mathrm{M}$ when for $\mathrm{Fe}_{3} \mathrm{O}_{4}{ }^{\mathrm{a}}$ nanoparticles this value decreased to $0.1 \mathrm{M}$ (Figure 2).
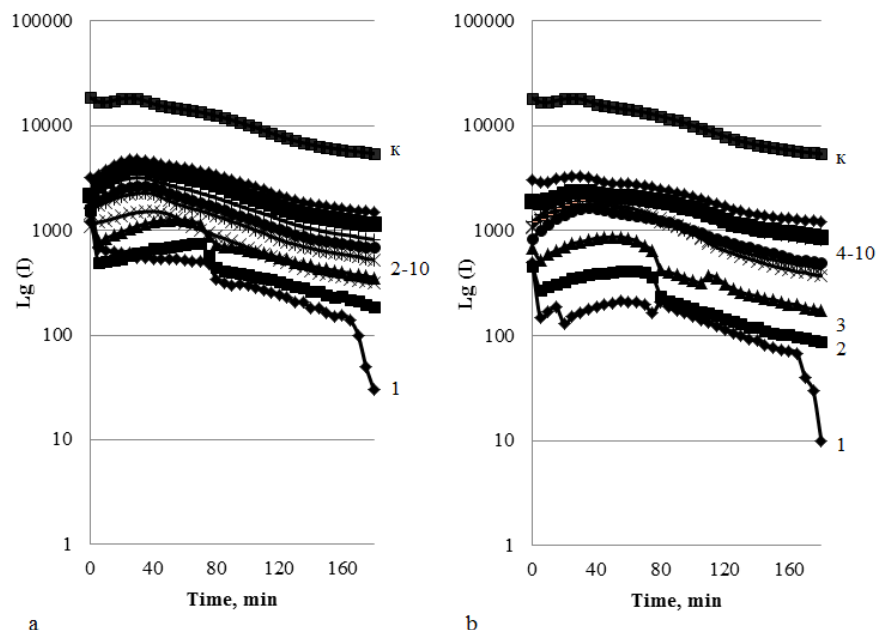

Figure 2. Dynamics of luminescence of $E$. coli $\mathrm{K} 12 \mathrm{TG} 1$ with cloned lux $C D A B E$ genes of P. leiongnathi 54D10 in contact with different concentrations of nanoparticles of a $-\mathrm{Fe}_{3} \mathrm{O}_{4}{ }^{\mathrm{a}}$ and $\mathrm{b}-\mathrm{Fe}_{3} \mathrm{O}_{4}{ }^{\mathrm{b}}$

0,5 (1) M; 0,25 (2) M; 0,1 (3) M; 0,05 (4) M; 0,025 (5) M; 0,0125 (6) M; 0,00625 (7) M; 0,003125 (8) M; 0,00156 (9) M; 0,000781 (10) M; c - control 
Further testing of serial dilutions concentrations of $\mathrm{Fe}_{3} \mathrm{O}_{4}{ }^{\text {ab }}$ nanoparticles in spectrum from 0.05 to $6 \times 6 \times 10^{-6}$ showed no effect on bioluminescence of E.coli K12 TG1 with cloned genes lux CDABE-P.leiongnathi 54 D10.

In contrast to samples of nanoparticles, Fe-Co alloy nanoparticles demonstrated highly toxic prolonged effect. So the range of concentrations from 4 to $0.00625 \mathrm{M}$ (Figure 3) produced complete suppression of luminescence of bacteria and is characterized as acute toxic. 50\% inhibition of bacterial bioluminescence is observed at concentration of $0.003125 \mathrm{M}$.

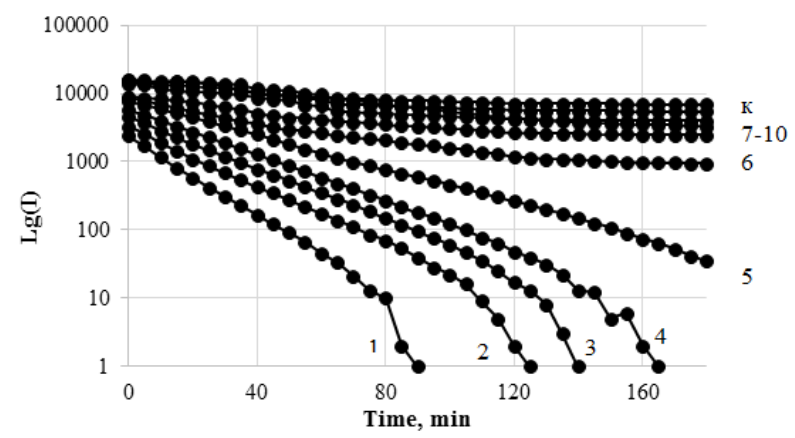

Figure 3. Dynamics of luminescence of $E$. coli K12 TG1 with cloned lux CDABE genes of P. leiongnathi 54D10 in contact with different concentrations of FeCo alloy nanoparticles

0,1 (1) M; 0,05 (2) M; 0,025 (3) M; 0,0125 (4) M; 0,00625 (5) M; 0,003125 (6) M; 0,001563 (7) M; 0,000781 (8) M; 0,000391 (9) M; 0,000195 (10) M; c-control

Further dilutions of $0.001563-6 \times 10^{-6} \mathrm{M}$ had no effect on dynamics of bacterial luminescence compared to control.

The above results were used to construct dose-response curves (Figure 4) for each of the tested nanoparticle samples. The $\mathrm{EC}_{50}$ values corresponding to the molar concentrations of iron nanoparticles and its oxides causing $50 \%$ inhibition of bacterial bioluminescence at different durations of exposure were also determined (Table 3 ).

Table 3. Values of $\mathrm{EC}_{50}(\mathrm{M})$ in contact of luminescent strain of E.coli with iron nanoforms

\begin{tabular}{llll}
\hline Nanoparticles, $M$ & \multicolumn{2}{l}{ Duration of the contact, min } \\
\cline { 2 - 4 } & 60 & 120 & 180 \\
$\mathrm{Fe}^{\mathrm{a}}$ & $0,05 \pm 0,00031$ & $0,05 \pm 0,00031$ & $0,05 \pm 0,00031$ \\
$\mathrm{Fe}^{\sigma}$ & $>0,25$ & $>0,25$ & $>0,25$ \\
$\mathrm{Fe}_{3} \mathrm{O}_{4}{ }^{\mathrm{a}}$ & $0,1 \pm 0,002$ & $0,1 \pm 0,002$ & $0,1 \pm 0,002$ \\
$\mathrm{Fe}_{3} \mathrm{O}_{4}{ }^{\mathrm{b}}$ & $>0,25$ & $>0,25$ & $>0,25$ \\
$\mathrm{FeCo}$ & $0,003125 \pm 0,0001$ & $0,003125 \pm 0,00002$ & $0,003125 \pm 0,00003$ \\
\hline
\end{tabular}

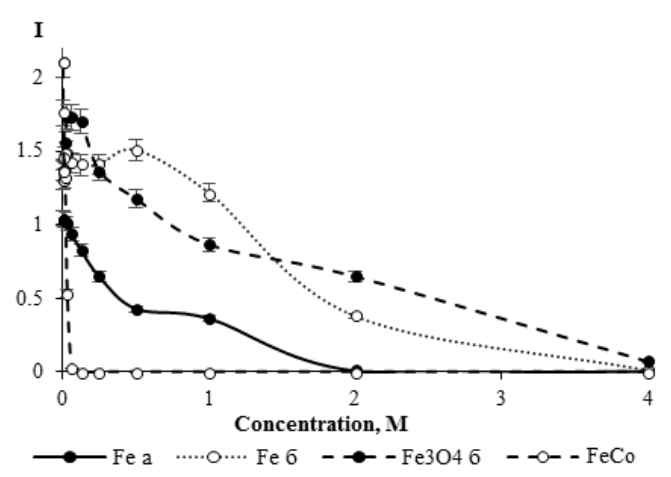

Figure 4. The relative values of luminous intensity for a luminescent strain of $E$. coli in contact with iron nanoparticles of different size and form; the ordinate is the relative value of luminescence intensity in comparison with the control 
Based on similar calculations of $\mathrm{EC}_{50}$ the levels of toxicity of the tested nanoparticle samples to the genetically engineered luminescent strain of $E$. coli decrease in the following order: $\mathrm{FeCo} \rightarrow \mathrm{Fe}^{\mathrm{a}} \rightarrow \mathrm{Fe}_{3} \mathrm{O}_{4}{ }^{\mathrm{a}} \rightarrow \mathrm{Fe}^{\mathrm{b}}=\mathrm{Fe}_{3} \mathrm{O}_{4}{ }^{\mathrm{b}}$.

\section{Discussion}

The results showed that sols of iron nanoparticles and iron oxides nanoparticles have biological activity in a wide range of concentrations and demonstrate biotic characteristics in relation to living systems both in small and relatively high doses.

Our results correspond to the results of other authors by toxicity of nanoparticles in the bioluminescence inhibition test. The order of decreasing toxicity from zinc oxide nanoparticles to iron dioxide nanoparticles $(\mathrm{ZnO}>$ $\mathrm{CuO}>\mathrm{NiO}>\mathrm{Fe} 2 \mathrm{O} 3$ ) has been described in the study of Ko KS et al., (2014) and slight toxic effect of iron nanoforms comparing with nanoparticles of other metals has been noted. Low toxicity of iron nanoparticles preparation which toxicity (EU50) appears at doses above 100mM has been described in the study of Deryabin D. G. et al., (2011). Similar results confirming low toxicity of iron nanoparticles are described in conducting of cultural research. The results of these studies demonstrate the ability of iron nanoparticles to inhibition of vital functions of bacteria cells but do not lead to the development of acute bactericidal effect in small doses (Tilston et al., 2013; Ismail R. A., 2015).

At the same time FeCo alloy nanoparticles showed signs of acute toxicity in relation to the test object in small doses as opposed to iron nanoparticles and iron oxide nanoparticles. Combined use of iron and cobalt nanoparticles leads to potentiation of toxic effect. In presence of iron and cobalt nanoparticles $\mathrm{EC}_{50}$ increases in dozens of times (83) (by comparison $\mathrm{Fe}^{\mathrm{b}} \mathrm{EC}_{50}-0.25$ and $\mathrm{FeCo}_{50}$ alloy-0.003-) at all stages of contact, i.e. toxicity is characterized by prolonged manifestation. Such effect of alloy nanoparticles is determined by the chemical composition of the compounds and in particular by the presence of cobalt ( $30 \%$ of alloy). It is known that cobalt oxide nanoparticles in small quantities lead to the formation in cell cultures of reactive oxygen species and activation of oxidases, development of oxidative stress in cells and activate apoptotic factors (Chattopadhyay et al., 2015). Presumably the presence of cobalt in the alloy leads to an increase of toxic properties of iron reducing the toxic effect of its own as described for other combinations of nanoparticles (Li et al., 2015).

Comparison of effect of iron nanoparticle and its oxides allows to make a supposition that biological activity depends not only on the chemical composition but also on the size. Composition of studied preparations includes nanoparticles of size from 80 to $95 \mathrm{~nm}$ including various forms of oxides and metals. Individual comparison of iron nanoparticles and iron oxide nanoparticles showed an increase of biological activity with the decrease of particles size. Changes in the structure of the electron shell of the particles occurring in contact with the biological system explain the differences in the properties of different size particles (Chihao Liow, 2012; Encai Hao and George C. Schatz., 2004). Similar results with regard to the connection between size and exerted effect has been described earlier (Yang L, 2015; Müller K., 2007; Raynal I., 2004; SS Yu, 2011; Yu SS, 2012).

Change of direct dependence between the size and biological effect observed when comparing the iron nanoparticles and their oxides may be explained by changes in the oxides structure. Based on literature data some form of oxide nanoparticles and nanoparticles derivatives may have not only toxic effect on the cell but also safety effect e.g. by inactivating the active forms of oxygen formed in the development of oxidative stress (Seung Soo Lee, 2013; Shcherbakov A. B., 2015; Yongye Liang, 2011 ).

\section{Conclusion}

Thus, iron nanoparticles and nanoparticles of its oxides in relation to E.coli were characterized as non-toxic or slightly toxic. All test variations of nanoparticles possess similar biological activity stable over time with low variability in the narrow concentration range from 0.25 to $0.05 \mathrm{M}$. These concentrations can be defined as a biologically active in relation to living systems.

\section{Acknowledgements}

This research was done with the financial support of the Russian Science Foundation №14-36-00023.

\section{References}

Ajdary, M., Ghahnavieh, M. Z., \& Naghsh, N. A. (2015). Sub-chronic toxicity of gold nanoparticles in male mice. $d v$ Biomed Res., 25(4), 67. http://dx.doi.org/10.4103/2277-9175.153890

Chattopadhyay, S., Dash, S. K., Tripathy, S., Das, B., Mandal, D., Pramanik, P., \& Roy, S. (2015). Toxicity of cobalt oxide nanoparticles to normal cells; an in vitro and in vivo study. Chem Biol Interact., 25(226), 58-71. 
http://dx.doi.org/10.1016/j.cbi.2014.11.016

Chihao, L., Fanben, M., Chen, X. D., \& Li, S. Z. (2014). Dependence of Plasmonic Properties on Electron Densities for Various Coupled Au Nanostructures. J. Phys. Chem. C, 118(47), 27531-27538. http://dx.doi.org/10.1021/jp5099975

Deryabin, D. G., Aleshina, E. S., Deryabina, T. D., \& Efremova, L.V. (2011). Biological activity of ions, nano and microparticles of $\mathrm{Cu}$ and $\mathrm{Fe}$ in the test of inhibition of bacterial bioluminescence. Questions of biological, medical and pharmaceutical chemistry, 6, 31-36.

Dragavon, J., Blazquez, S., Rekiki, A., Samson, C., Theodorou, I., Rogers, K. L., .. S Shorte, S. L. (2012). In vivo excitation of nanoparticles using luminescent bacteria. Proc Natl Acad Sci USA, 5, 109(23), 8890-5. http://dx.doi.org/10.1073/pnas.1204516109

Encai, H., \& George, C. S. (2004). Electromagnetic fields around silver nanoparticles and dimers. J. Chem. Phys. $120,357$.

Gong, M., Yang, H., Zhang, S., Yang, Y., Zhang, D., Qi, Y., \& Zou, L. (2015). Superparamagnetic core/shell GoldMag nanoparticles: size-, concentration- and time-dependent cellular nanotoxicity on human umbilical vein endothelial cells and the suitable conditions for magnetic resonance imaging. J Nanobiotechnology, 25, 13(1), 24. http://dx.doi.org/10.1186/s12951-015-0080-x.

Ismail, R. A., Sulaiman, G. M., Abdulrahman, S. A., \& Marzoog, T. R. (2015). Antibacterial activity of magnetic iron oxide nanoparticles synthesized by laser ablation in liquid. Mater Sci Eng C Mater Biol Appl., 53, 286-97. http://dx.doi.org/10.1016/j.msec.2015.04.047

Jiang, B., Perrin, L., Kats, D., Meade, T., \& Ameer, G. (2015). Enabling non-invasive assessment of an engineered endothelium on ePTFE vascular grafts without increasing oxidative stress. Biomaterials, 5(69), 110-120. http://dx.doi.org/ 10.1016/j.biomaterials.2015.07.064

Ko, K. S., \& Kong, I. C. (2014). Toxic effects of nanoparticles on bioluminescence activity, seed germination, and gene mutation. Appl Microbiol Biotechnol, 98(7), 3295-303. http://dx.doi.org/10.1007/s00253-013-5404-x

Lee, S. S., Song, W. S., Minjung, C., Hema, L., Puppala, P. N., Zhu, H. G., Laura, S., \& Vicki, L. C. (2013). Antioxidant Properties of Cerium Oxide Nanocrystals as a Function of Nanocrystal Diameter and Surface Coating. CS Nano, 7(11), 9693-9703. http://dx.doi.org/10.1021/nn4026806

Li, L., Fernández-Cruz, M. L., Connolly, M., Conde, E., Fernández, M., \& Schuster, M. (2015). The potentiation effect makes the difference: non-toxic concentrations of $\mathrm{ZnO}$ nanoparticles enhance $\mathrm{Cu}$ nanoparticle toxicity in vitro. Navas Sci Total Environ, 505, 253-260. http://dx.doi.org/10.1016/j.scitotenv.2014.10.020

Liang, Y. Y., Li, Y. G., Wang, H. L., Zhou, J. G., Wang, J., Tom, R., \& Dai, H. J. (2011). $\mathrm{Co}_{3} \mathrm{O}_{4}$ nanocrystals on graphene as a synergistic catalyst for oxygen reduction reaction. Nature Materials, 10, 780-786. http://dx.doi.org/10.1038/nmat3087

Liu, R., Liu, H. H., Ji, Z., Chang, C. H., Xia, T., Nel, A. E., \& Cohen, Y. (2015). Evaluation of Toxicity Ranking for Metal Oxide Nanoparticles via an in vitro Dosimetry Model. ACS Nano. August 18.

Melancon, M. P., Zhou, M., \& Li C. (2011). Cancer theranostics with near-infrared light-activatable multimodal nanoparticles. Acc. Chem. Res., 18, 44(10), 947-956. http://dx.doi.org/10.1021/ar200022e.

Müller, K., Skepper, J. N., Posfai, M., Trivedi, R., Howarth, S., Corot, C., Lancelot, E., Thompson, P. W., Brown, P., \& Gillard, J. H. (2007). Effect of ultrasmall superparamagnetic iron oxide nanoparticles (Ferumoxtran-10) on human monocyte-macrophages in vitro. Biomaterials, 28(9), 1629-42. Epub 2006 Dec 18.

Raynal, I., Prigent, P., Peyramaure, S., Najid, A., Rebuzzi, C., \& Corot, C. (2004). Macrophage endocytosis of superparamagnetic iron oxide nanoparticles: mechanisms and comparison of ferumoxides and ferumoxtran-10. Invest Radiol, 39(1), 56-63.

Shcherbakov, A. B., Zholobak, N. M., Baranchikov, A. E., Ryabova, A. V., \& Ivanov, V. K. (2015). Cerium fluoride nanoparticles protect cells against oxidative stress. Mater Sci Eng C Mater Biol Appl., 50, 151-9. http://dx.doi.org/10.1016/j.msec.2015.01.094

Tilston, E. L., Collins, C. D., Mitchell, G. R., Princivalle, J., \& Shaw, L. J. (2013). Nanoscale zerovalent iron alters soil bacterial community structure and inhibits chloroaromatic biodegradation potential in Aroclor 1242-contaminated soil. Environ Pollut., 173, 38-46. http://dx.doi.org/10.1016/j.envpol.2012.09.018 
Yang, L., Kuang, H., Zhang, W., Aguilar, Z. P., Xiong, Y., Lai, W., Xu, H., \& Wei, H. (2015). Size dependent biodistribution and toxicokinetics of iron oxide magnetic nanoparticles in mice. Nanoscale, 14, 7(2), 625-36. http://dx.doi.org/10.1039/c4nr05061d

Yu, S. S., Lau, C. M., Thomas, S. N., Jerome, W. G., Maron, D. J., Dickerson, J. H., ... Giorgio, T. D. (2012). Size- and charge-dependent non-specific uptake of PEGylated nanoparticles by macrophages. Int $J$ Nanomedicine, 7, 799-813. http://dx.doi.org/10.2147/IJN.S28531

Yu, S. S., Scherer, R. L., Ortega, R. A., Bell, C. S., O'Neil, C. P., Hubbell, J. A., \& Giorgio, T. D. (2011). Enzymatic- and temperature-sensitive controlled release of ultrasmall superparamagnetic iron oxides (USPIOs). J Nanobiotechnology, 27(9), 7. http://dx.doi.org/10.1186/1477-3155-9-7

\section{Copyrights}

Copyright for this article is retained by the author(s), with first publication rights granted to the journal.

This is an open-access article distributed under the terms and conditions of the Creative Commons Attribution license (http://creativecommons.org/licenses/by/3.0/). 